\title{
Erratum
}

\section{Erratum to Guidance on Determining Indispensability and Balancing Potential Benefits of Animal Experiments with Costs to the Animals with Specific Consideration of EU Directive 2010/63/EU}

Toni Lindl ${ }^{1}$, Ulrike Gross ${ }^{2}$, Irmela Ruhdel ${ }^{2}$, Sonja von Aulock ${ }^{3}$, and Manfred Völkel ${ }^{4}$

${ }^{1}$ Institut für angewandte Zellkultur, Munich, Germany; ${ }^{2}$ German Animal Welfare Federation, Animal Welfare Academy, Neubiberg, Germany; ${ }^{3}$ University of Konstanz, Germany; ${ }^{4}$ Tierversuchskommission Nordbayern, Government of Lower Franconia, Würzburg, Germany

In this workshop report which appeared in ALTEX (2012), 29(2), 219- 228, PMID: 22562491 part G of Box 1 was omitted.

Box 1 (revised)

Box 1: Form for the cost-benefit analysis of proposed experimental scientific procedures on animals

Application/Procedure number

\begin{tabular}{|l|l|l|l|}
\hline A & \multicolumn{3}{|l|}{$\begin{array}{l}\text { Determination of the level of severity of the experimental animal group with the highest level of } \\
\text { severity in the procedure (Directive 2010/63/EU, Annex VIII) according to information given in the opinion of } \\
\text { the designated veterinarian }\end{array}$} \\
\hline$\square$ & A1 & Non-recovery*: & $\begin{array}{l}\text { Procedures which are performed entirely under general anaesthesia from which the animal shall not } \\
\text { recover consciousness shall be classified as 'non-recovery'. }\end{array}$ \\
\hline$\square$ & A2 & Mild*: & $\begin{array}{l}\text { Procedures on animals as a result of which the animals are likely to experience short-term mild pain, } \\
\text { suffering or distress, as well as procedures with no significant impairment of the well-being or general } \\
\text { condition of the animals shall be classified as 'mild'. }\end{array}$ \\
\hline$\square$ & A3 & Moderate*: & $\begin{array}{l}\text { Procedures on animals as a result of which the animals are likely to experience short-term moderate } \\
\text { pain, suffering or distress, or long-lasting mild pain, suffering or distress as well as procedures } \\
\text { that are likely to cause moderate impairment of the well-being or general condition of the animals } \\
\text { shall be classified as 'moderate'. }\end{array}$ \\
\hline$\square$ & A4 & $\begin{array}{l}\text { Severe*: } \\
\text { Procedures on animals as a result of which the animals are likely to experience severe pain, } \\
\text { suffering or distress, or long- lasting moderate pain, suffering or distress as well as procedures, that } \\
\text { are likely to cause severe impairment of the well- being or general condition of the animals shall } \\
\text { be classified as 'severe'. }\end{array}$ \\
\hline
\end{tabular}

$\square$ mark as appropriate; * according to Directive 2010/63/EU, Annex VIII

Note: If the opinion of the designated veterinarian is lacking: "Application incomplete, return to applicant". Perform own appraisal of severity level, see Directive 2010/63/EU Annex VIII, Section III, Examples of different types of procedure.

Comments: 


\begin{tabular}{|l|l|l|c|}
\hline B & \multicolumn{2}{|l|}{$\begin{array}{l}\text { Designation of humane endpoints given in the application (2010/63/EU, Recital 5, 10; 13; 14; 15; 23; and 30; } \\
\text { Art. 13 Paragraph 3 }\end{array}$} & Continue with C \\
\hline B1 & $\begin{array}{l}\text { Non-recovery procedure: humane endpoints are not relevant. } \\
\text { Animals are killed under anaestesia }\end{array}$ & No $\square$ & Continue with B2 \\
\hline B2 & $\begin{array}{l}\text { Procedure classified as "mild" or "moderate" in the application: if in } \\
\text { the course of the experiment a "severe" level suffering occurs, the animal } \\
\text { is taken out of the experiment immediately and killed without causing } \\
\text { any further suffering }\end{array}$ & Yes $\square$ & Continue with B3 \\
\hline B3 & $\begin{array}{l}\text { procedure classified as "severe" } \\
\text { It is possible that the criteria for the humane endpoints surpass upper } \\
\text { limit of the category "severe" (such procedures are prohibited, EU, 2010, } \\
\text { Recital, 23) }\end{array}$ & $\begin{array}{l}\text { No } \square \\
\text { Continue with G2 }\end{array}$ & \begin{tabular}{l} 
Continue with C \\
\hline
\end{tabular} \\
\hline
\end{tabular}

$\square$ mark as appropriate

\section{Comments:}

\begin{tabular}{|l|l|l|l|}
\hline C & \multicolumn{3}{|l|}{ Determination of the indispensability (Lorz and Metzger, 2008, para. 7 (35-39); 2010/63/ EU Art 4 (1); Art 13 (1)) } \\
\hline C & $\begin{array}{l}\text { The applicant has argued convincingly that no scientifically sufficient, } \\
\text { justifiable and practicable alternatives such as cell and tissue cultures, } \\
\text { computer programs or respective in vitro tests are available. }\end{array}$ & $\begin{array}{c}\text { Yes } \square \\
\text { No } \square\end{array}$ & $\begin{array}{l}\text { Continue with D } \\
\text { Continue with G2 }\end{array}$ \\
\hline
\end{tabular}

$\square$ mark as appropriate

\begin{tabular}{|c|c|c|c|}
\hline D & Classification into purpose of procedure: translational or basic rese & $(2010 / 63$ & \\
\hline D1 & $\begin{array}{l}\text { The experimental procedure is carried out for the purpose of translational } \\
\text { or applied research (2010/63/EU Article } 5 \mathrm{~b}, \mathrm{c} \text {, or } \mathrm{g})\end{array}$ & $\begin{array}{l}\text { Yes } \square \\
\text { No } \square\end{array}$ & $\begin{array}{l}\text { Continue with } \mathrm{E} \\
\text { Continue with } \mathrm{D} 2\end{array}$ \\
\hline D2 & $\begin{array}{l}\text { The experimental procedure is carried out for the purpose of translational } \\
\text { or applied research - protection of the environment or of species diversity } \\
\text { (2010/63/EU Article 5(d) and (e)) }\end{array}$ & $\begin{array}{l}\text { Yes } \square \\
\text { No } \square\end{array}$ & $\begin{array}{l}\text { Continue with } \mathrm{E} \\
\text { Continue with D3 }\end{array}$ \\
\hline D3 & $\begin{array}{l}\text { The experimental procedure is carried out for the purpose of higher } \\
\text { education or training (2010/63/EU Article } 5(f))\end{array}$ & $\begin{array}{l}\text { Yes } \square \\
\text { No } \square\end{array}$ & $\begin{array}{l}\text { Continue with F1.1 } \\
\text { Continue with D4 }\end{array}$ \\
\hline D4 & $\begin{array}{l}\text { The experimental procedure is carried out for the purpose of basic } \\
\text { research (2010/63/EU Article 5a) }\end{array}$ & Yes $\square$ & Continue with F2 \\
\hline
\end{tabular}

$\square$ mark as appropriate

Comments: 


\begin{tabular}{|c|c|c|c|c|}
\hline E & $\begin{array}{l}\text { The educational } \\
\text { or the environme } \\
\text { procedure (EU, } 2\end{array}$ & $\begin{array}{l}\text { alue or the probability of delivering results that are tr } \\
\text { tor of delivering clinically relevant results in this sci } \\
10, \text { Art } 13(2 c) \text { ) }\end{array}$ & $\begin{array}{l}\text { sferable } \\
\text { tific disc }\end{array}$ & $\begin{array}{l}\text { s, other animals, } \\
\text { g this experimental }\end{array}$ \\
\hline E1 & $\begin{array}{l}\text { Can be assumed } \\
\text { because }\end{array}$ & $\begin{array}{l}\text { The transferability of results from experimental } \\
\text { procedures to humans, animals, or the environment in } \\
\text { this scientific discipline has previously been de- } \\
\text { monstrated for the same or a similar research question } \\
\text { and is argued using the relevant scientific literature, } \\
\text { or the educational value has been argued convincingly }\end{array}$ & $\begin{array}{l}\text { Yes } \square \\
\text { No } \square\end{array}$ & $\begin{array}{l}\text { Continue with F1 } \\
\text { Continue with E2 }\end{array}$ \\
\hline E2 & $\begin{array}{l}\text { Is unclear } \\
\text { because }\end{array}$ & $\begin{array}{l}\text { Newly created genetically modified animals are } \\
\text { to be used where relevance cannot be predicted } \\
\text { And/or the literature quoted is insufficient, or } \\
\text { the educational value is doubtful }\end{array}$ & $\begin{array}{l}\text { Yes } \square \\
\text { No } \square\end{array}$ & $\begin{array}{l}\text { Continue with F2 } \\
\text { Continue with E3 }\end{array}$ \\
\hline E3 & $\begin{array}{l}\text { Is unlikely } \\
\text { because }\end{array}$ & $\begin{array}{l}\text { The transferability of results from the proposed animal } \\
\text { model to humans, other animals or the environment in } \\
\text { this scientific discipline has not previously been } \\
\text { shown based on the scientific literature cited in } \\
\text { the proposal, or the educational value is lacking. }\end{array}$ & Yes $\square$ & Continue with F3 \\
\hline
\end{tabular}

$\square$ mark as appropriate

Comments:

F $\quad$ Cost-benefit analysis between the potential benefits to humans, animals or the environment and the pain, suffering and distress caused to the experimental animals. The more severe the proposed procedure, the greater the weight of the reasons needs to be to legitimise it (EU, 2010, 38 (2)(d); Lorz and Metzger, 2008, para 7 (54-58) and para 8 (19-23).

A procedure may not be performed if it involves severe pain, suffering or distress that is likely to be long-lasting and cannot be ameliorated (Directive 2010/63/EU, 15(2)). A provisional measure may be adoped in case of exceptional and scientifically justifiable reasons (Directive 2010/63/EU, 55(3)).

\begin{tabular}{|c|c|c|c|c|c|}
\hline \multirow[t]{4}{*}{$\mathrm{F} 1$} & $\begin{array}{l}\mathrm{F} 1.1 .1 \\
\square\end{array}$ & All severity levels & $\begin{array}{l}\text { The experimental procedure } \\
\text { is carried out for the purpose } \\
\text { of higher education or training } \\
\text { (2010/63/EU Article } 5(f)) \text {; D3 }\end{array}$ & $\begin{array}{l}\text { The educational value has } \\
\text { been shown }\end{array}$ & Continue with $\mathrm{G} 1$ \\
\hline & $\begin{array}{l}\mathrm{F} 1.1 .2 . \\
\square\end{array}$ & All severity levels & $\begin{array}{l}\text { The experimental procedure } \\
\text { is carried out for the purpose } \\
\text { of higher education or training } \\
(2010 / 63 / \text { EU Article } 5(f)) \text {; D3 }\end{array}$ & $\begin{array}{l}\text { The educational value has } \\
\text { not been shown }\end{array}$ & Continue with G2 \\
\hline & $\begin{array}{l}\mathrm{F} 1.2 \\
\square\end{array}$ & $\begin{array}{l}\text { All severity levels } \\
\text { The possibility of } \\
\text { exceeding the category } \\
\text { "severe" is excluded }\end{array}$ & $\begin{array}{l}\text { The procedure falls into } \\
\text { applied research, i.e. D1 or D2 }\end{array}$ & $\begin{array}{l}\text { Success of the proposal } \\
\text { can be assumed according } \\
\text { to } E 1 \text {. }\end{array}$ & Continue with $\mathrm{G} 1$ \\
\hline & $\begin{array}{l}\mathrm{F} 1.3 \\
\square\end{array}$ & $\begin{array}{l}\text { The severity level is } \\
\text { "severe," i.e. A4. } \\
\text { The possibility of } \\
\text { exceeding the category } \\
\text { "severe" is NOT excluded }\end{array}$ & $\begin{array}{l}\text { The procedure falls into } \\
\text { applied research: D1 or D2. }\end{array}$ & $\begin{array}{l}\text { Success of the proposal } \\
\text { can be assumed according } \\
\text { to } E 1 \text {. }\end{array}$ & Continue with $\mathrm{G} 2$ \\
\hline \multirow[t]{2}{*}{$\mathrm{F} 2$} & $\begin{array}{l}\mathrm{F} 2.1 \\
\square\end{array}$ & $\begin{array}{l}\text { The severity level is } \\
\text { "non-recovery" or } \\
\text { "mild," i.e. A1 or A2. }\end{array}$ & $\begin{array}{l}\text { The procedure falls into } \\
\text { basic research, i.e. D4. }\end{array}$ & $\begin{array}{l}\text { The applicability of } \\
\text { the results is unclear } \\
\text { (cannot be judged). }\end{array}$ & Continue with $\mathrm{G} 1$ \\
\hline & $\begin{array}{l}\mathrm{F} 2.2 \\
\square\end{array}$ & $\begin{array}{l}\text { The severity level is " } \\
\text { moderate" or "severe," i.e. } \\
\text { A3 or A4 }\end{array}$ & $\begin{array}{l}\text { The procedure falls into } \\
\text { basic research, i.e. D4. }\end{array}$ & $\begin{array}{l}\text { The applicability of } \\
\text { the results is unclear } \\
\text { (cannot be judged). }\end{array}$ & Continue with $\mathrm{G} 2$ \\
\hline
\end{tabular}




\begin{tabular}{|l|l|l|l|l|l|}
\hline & $\begin{array}{l}\text { F2.3 } \\
\square\end{array}$ & $\begin{array}{l}\text { The severity level is } \\
\text { "moderate" or "severe," i.e. } \\
\text { A3 or A4. }\end{array}$ & $\begin{array}{l}\text { The procedure falls into } \\
\text { basic research, i.e. D4. }\end{array}$ & $\begin{array}{l}\text { Both the exceptional } \\
\text { importance of the research } \\
\text { and the possibility of } \\
\text { delivering transferable } \\
\text { results are convincingly } \\
\text { argued based on citations } \\
\text { from the scientific literature } \\
\text { (applied research). }\end{array}$ & Continue with G1 \\
\hline F3 & $\begin{array}{l}\text { F3.1 } \\
\square\end{array}$ & All severity levels & $\begin{array}{l}\text { The procedure falls into } \\
\text { applied research, i.e. D1 or D2 } \\
\text { i.e. E3. }\end{array}$ & $\begin{array}{l}\text { Success of the proposal } \\
\text { cannot be assumed, }\end{array}$ & Continue with G2 \\
\hline
\end{tabular}

$\square$ mark as appropriate

Comments:

\begin{tabular}{|c|c|c|}
\hline G & Dec & on based on the cost-benefit analysis \\
\hline$\square$ & G1 & $\begin{array}{l}\text { The application fulfills the regulatory requirements of the cost-benefit analysis. } \\
\text { It is probable that the aim of the procedure will be reached, the level of severity is balanced with the expected benefit } \\
\text { for humans, animals, or the environment and can be approved (EU, 2010, Annex VIII; Germany, 2010, para 7,8; } \\
\text { Lorz and Metzger, } 2008 \text { para } 7 \text { (54-59) and para } 8 \text { (19-23)). The application must pass further (formal and material) } \\
\text { assessments (Germany, 2010, para 7,8). }\end{array}$ \\
\hline$\square$ & G2 & $\begin{array}{l}\text { The application does not fulfill the regulatory requirements of the cost-benefit analysis in its current form. } \\
\text { It does not fulfill the requirements for the ethical defensibility of the use of vertebrates for scientific purposes (EU, 2010, } \\
\text { Annex VIII; Germany, 2010, para 7,8; Lorz and Metzger, 2008, para } 7(54-59) \text { and para } 8(19-23) \text { ) and therefore is } \\
\text { denied for the reasons given } \\
\text { or } \\
\text { in the case of open questions, incomplete or inconsistent data is deferred with a request for response from the } \\
\text { applicant because** } \\
\square \text { The upper threshold of severity is exceeded. } \\
\square \text { The animal experiments for the purpose of education can be replaced by alternative methods. } \\
\square \text { The monitoring intervals are too long in relation to the severity of the experiment or cannot be established. } \\
\square \text { Humane endpoints are lacking or are insufficient to prevent severe suffering. } \\
\square \text { The scientific argument that a higher animal number reduces the suffering to the individual animal is } \\
\text { insufficiently justified. } \\
\square \text { The ratio of animals that will die during the procedure is deemed too high. } \\
\square \text { The number of animals given in the application is deemed too high. } \\
\square \text { The high level of severity is not weighed up by an appropriate gain of transferable knowledge. } \\
\square \text { The hypotheses or research aims are not scientifically justified comprehensively. } \\
\square \text { The choice of species is not scientifically justified. } \\
\square \text { The indispensability of the approach is not demonstrated/justified. } \\
\square \text { The clinical relevance of the animal model is not scientifically justified based on clinical literature. } \\
\square \text { The expected results do not appear to be of exceptional importance for elementary needs of humans, } \\
\text { animals or the environment. } \\
\square \text { The appraisal of the ethical defensibility is not sufficiently explained/is lacking. }\end{array}$ \\
\hline
\end{tabular}

$\square$ mark as appropriate; ${ }^{*}$ not an exhaustive list

Comments: 